\title{
Water quality in equine production in Buenos Aires Province, Argentina
}

\author{
Mariana M. Vaccaro ${ }^{1,2}$ - Alejandra V. Volpedo ${ }^{1} \cdot$ Alberto García Liñeiro $^{2} \cdot$ Alicia Fernñandez Cirelli $^{1}$
}

Received: 14 October 2019 / Accepted: 13 February 2020 / Published online: 24 February 2020

(c) Springer Nature Switzerland AG 2020

\begin{abstract}
One of the key factors for equine production is water, its availability in sufficient quantity and adequate quality. Studies about water quality in equine production worldwide are limited and even more limited in Argentina (South America). However, the amount of horses in Argentina declared by National Service of Agri-Food Health and Quality is of 2.5 million heads approximately, being most of them in Buenos Aires Province. The aim is to characterize the water quality in equine production farms in Buenos Aires Province, Argentina. Groundwater samples were taken from 26 equine production farms where physicochemical parameters ( $\mathrm{pH}$, conductivity, total hardness, chlorides, nitrates and total dissolved solids), water wells' depth and the distance from the farms to the city of Buenos Aires were registered. The values of physicochemical parameters were correlated with the distance to the city of Buenos Aires to assess the influence of the alterations in groundwater quality resulting from pollution in the city of Buenos Aires and its periphery and the depth of the wells using the Spearman correlation $(p<0.05)$. The results of the work show that there is an association between farms' water quality and the distance to the city of Buenos Aires. The depth presents significant positive correlation with the conductivity, chloride and total dissolved solids and negative correlation with nitrates. This suggests that sources of groundwater near to the city of Buenos Aires present a lower water quality. In conclusion, the water equine production farms in Buenos Aires Province were negatively related to the distance from Buenos Aires city. Equine farms closest to the city $(<80 \mathrm{~km})$ may present different problems to be considered: the excessive salinity and the presence of nitrates from anthropic origin.
\end{abstract}

Keywords Groundwater · Equine farms · South America

\section{Introduction}

One of the key factors for equine production is water, its availability in sufficient quantity and adequate quality [1, 2]. Water is essential for horses since it takes part in vital and essential functions, such as tissues development, disposal of metabolic products through urine and sweating, milk production in mares, also contributing to the transport of food substances.
If the quality of drinking water for horses is not adequate, the animals may become sick and eventually die. For example, excessive chlorides and magnesium can lead to profuse diarrhea that leads to a painful symptomatology typical of the equine known as colic equine syndrome that could lead to the death of the animal [3].

The daily consumption of water may be between 20 and $60 L[4,5]$ depending on each animal and factors such as physical activity, work and exercise done, the atmospheric conditions as temperature, humidity, whether the animal

$\checkmark$ Mariana M. Vaccaro, mvaccaro@fvet.uba.ar | ${ }^{1}$ Unidad Ejecutora de Investigaciones en Producción Animal (INPA, UBA-CONICET), Ciudad Autónoma de Buenos Aires, Argentina. ${ }^{2}$ Cátedra de Salud y Producción Equina, Facultad de Ciencias Veterinarias, Universidad de Buenos Aires, Av. Chorroarín 280, C1427CWO Ciudad Autónoma de Buenos Aires, Argentina. 
is in lactating period, as well as the nature of the ration, since some food provides a certain amount of water. On the other hand, the type of activity the horse does also has an influence in water consumption (Table 1). For example, water consumption of gestating horses is $32-41 \mathrm{~L} / a n i m a l /$ day and full lactating 41-50 L/animal/day $[4,5]$.

Studies about water quality in equine production worldwide are limited [6-8] and even more limited in Argentina (South America) $[9,10]$. Hooda et al. [7] reviewed a water quality in livestock farming areas of the UK determining that the rational use of manure and mineral fertilizers can help reduce pollution problems arising from livestock farming practices and avoid the contamination of the water sources. Moreover, in Belgian equine farms, Burgess et al. [6] attributed for the first time horse deaths to extremely poor water quality (high salinity and sulfate toxicity).

Despite the amount of horses in Argentina declared by National Service of Agri-Food Health and Quality [11www. senasa.gov.ar] is of 2,442,130 heads, most of them are in Buenos Aires Province. Buenos Aires Province is the area of Argentina which has largest number of equine farms.

In this province are located the Federal Capital of Argentina (the city of Buenos Aires) and the great Buenos Aires, where more than 17 million people live. This is one of the most populous cities in the world with the higher industrial development of the country. This megacity and its periphery do not have an adequate water sanitation network. Domestic and industrial effluents are partially treated or untreated, and they are discharged into water bodies, which is a source of contamination for groundwater. So in many cases, agricultural production and small towns near the city of Buenos Aires find it difficult to have access to water quality sources because aquifers have different degree of pollution $[12,13]$. In this sense, the equine production closest to the city of Buenos Aires could have a lower water quality than those located further. The aim of this paper is to characterize water quality in equine production farms in Buenos Aires Province, Argentina.

\section{Materials and methods}

The 26 equine production farms studied are located in different areas of Buenos Aires Province (Pilar, Open Door, Exaltación de la Cruz, General Las Heras, Malvinas Argentinas, Moreno, Hurlingham, Cañuelas, Chivilcoy, Lujan, San Andrés de Giles and San Isidro) (Fig. 1). The selection of these farms was based on its importance in the production of jumping horses of the province of Buenos Aires. These equine farms have from 11 to 410 horses each. Some of the sampling locations are in the outskirts of city of Buenos Aires mainly in the northern and western areas. In this area, the groundwater comes from the Puelches and Pampeano aquifers. The Pampeano aquifer acts as a way to recharge and discharge the Puelches aquifer with the resulting transfer of polluting substances. These aquifers have in their high and low zones sodium bicarbonate waters and sodium sulphated chloride, respectively $[12,14]$. The $\mathrm{pH}$ of the same zones fluctuates between 7.4 and 8.03 , the total dissolved solids are between 800 and $2200 \mathrm{mg} / \mathrm{L}$, and the conductivity between 800 and $5000 \mu \mathrm{s} / \mathrm{cm}$.

Groundwater samples were taken from a faucet directly connected to the water well in each equine production farm.

The depth of the water source was registered, and water samples were taken following the protocol [15] in sterilized recipients and were kept refrigerated until they were taken to the laboratory.

The following physicochemical parameters were registered, $\mathrm{pH}$, conductivity $(\mu \mathrm{S} / \mathrm{cm})$ through Hanna $\mathrm{Hi}$ 255 , total hardness $(\mathrm{mg} / \mathrm{L})$ determined by EDTA titration method [15] chlorides (mg/L) by the Argentometric method, nitrates $(\mathrm{mg} / \mathrm{L}$ ) by the cadmium reduction method with HACH DR 890 and the total dissolved solids
Table 1 Water consumption according to the activity done by the horse and levels of chlorides in samples

\begin{tabular}{llllllrr}
\hline Type of activity & Liters/animal/day & \multicolumn{2}{l}{\begin{tabular}{l} 
Levels of chlorides \\
\cline { 3 - 7 }
\end{tabular}} & & $\begin{array}{l}\text { High concentra- } \\
\text { tions: }>100 \mathrm{mg} / \mathrm{L}\end{array}$ & $\begin{array}{l}\text { Moderate } \\
\text { concentrations: } \\
40-50 \mathrm{mg} / \mathrm{L}\end{array}$ & $\begin{array}{l}\text { Low concentra- } \\
\text { tions <20 mg/L }\end{array}$ \\
\hline At rest & $17-34$ & 1700 & $3400^{*}$ & 680 & 1700 & 340 & 680 \\
Gestation & $32-41$ & $3200^{*}$ & $4100^{*}$ & 1280 & 2050 & 640 & 820 \\
Full Lactation & $41-50$ & $4100^{*}$ & $5000^{*}$ & 1640 & 2050 & 820 & 820 \\
Average work & $41-63$ & $4100^{*}$ & $6300^{*}$ & 1640 & $3150^{*}$ & 820 & 1260 \\
Heavy work & $54-63$ & $5400^{*}$ & $6300^{*}$ & 2160 & $3150^{*}$ & 1080 & 1260 \\
\hline
\end{tabular}

Average consumption of animal drink water for horses of 992.08 pounds live weight (ambient temperature of $59^{\circ}$ to $69.800^{\circ} \mathrm{F}$ )

*Water quality levels guidelines chlorides $>3000$ mg/L [22] 
Fig. 1 Sampling Sites of Farms. 1-11-12-14-15-22- General Las Heras, 2-San Isidro, 3-Malvinas Argentinas, 4-Moreno, 5-6-8-10-11-13-21-23 Pilar, 7- Cañuelas, 9-18 San Andrés de Giles, 12- Open Door, 16-17 Moreno, 19-20-26 Hurlingham, 24-Chivilcoy, 25-Exaltación de la Cruz

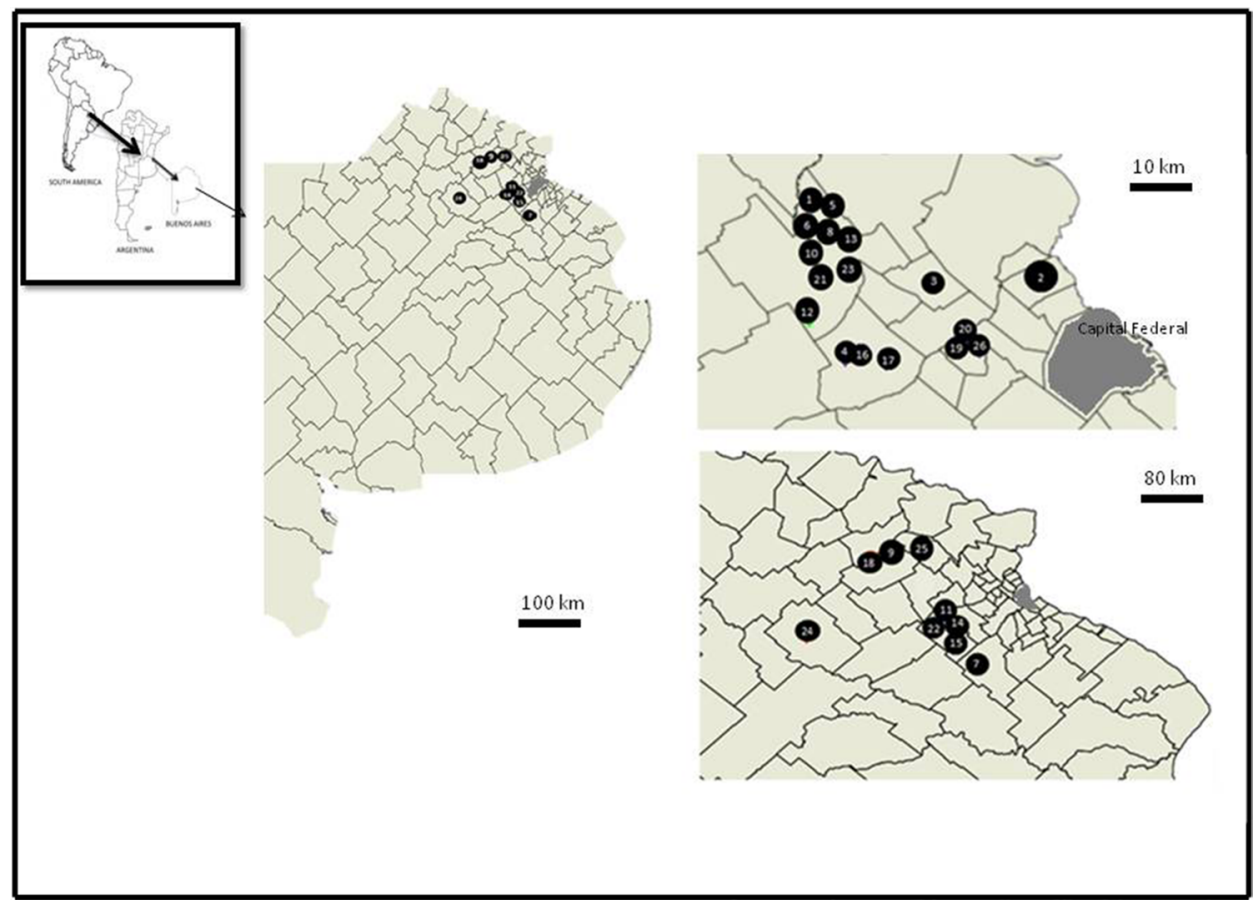

(TDS, mg/L) using the drying method at $103-105^{\circ} \mathrm{C}$ (Method 2540C, [15]). TDS is a measure of the total ionic concentration of dissolved minerals in water. TDS is composed of the following principal cations (or positively charged ions): sodium $\left(\mathrm{Na}^{+}\right)$, calcium $\left(\mathrm{Ca}^{2+}\right)$, potassium $\left(\mathrm{K}^{+}\right)$, magnesium $\left(\mathrm{Mg}^{+2}\right)$ and anions (or negatively charged ions): chloride $\left(\mathrm{Cl}^{-}\right)$, sulfate $\left(\mathrm{SO}_{4}{ }^{2-}\right)$, carbonate $\left(\mathrm{CO}_{3}{ }^{2-}\right)$, bicarbonate $\left(\mathrm{HCO}_{3}{ }^{-}\right)$and to a lesser extent by nitrate $\left(\mathrm{NO}_{3}{ }^{-}\right)$, iron $\left(\mathrm{Fe}^{3+}\right)$, manganese $\left(\mathrm{Mn}^{2+}\right)$ and fluoride $\left(\mathrm{F}^{-}\right)$. Chloride is a major component of dissolved solids. The total dissolved solids were determined in a sub-sample of ten farms that had three different levels of chlorides (high concentrations: $>100 \mathrm{mg} / \mathrm{L}$; moderate concentrations: $40-50 \mathrm{mg} / \mathrm{L}$ and low concentrations $<20 \mathrm{mg} / \mathrm{L}$ ). Parameter values were compared to the recommended guide levels for drinking water for livestock of the CCME [16] and USEPA [17]. These guide values are general values for animal production and not specific to horses.

The values of physicochemical parameters were correlated with the distance to the city of Buenos Aires and the depth of the wells using the Spearman correlation $(p<0.05)$.

A principal components analysis (PCA) was performed to identify the main physicochemical parameters that influence water quality in relation to the distance to the city of Buenos Aires. The selection of PCs (axes) for interpretation was performed using a screen plot [18]. Data analyses were made by using the Infostat software [19].

\section{Results and discussion}

Groundwater sources from the farms studied are generally drillings of Puelches and Pampeano aquifers. The wells depth was between 14 and $80 \mathrm{~m}$, the wells of shallow depths the ones associated with the Pampeano aquifer, whereas the ones between 70 and $80 \mathrm{~m}$ come from Puelches aquifer.

Results show that $\mathrm{pH}$ values of the water samples from the water table and semi-artesian wells are on the range of 6.50-7.73 and did not exceed the optimal range for animal drink water suggested by Canadian Environmental Quality Guidelines CEQFs [20], Equine Facilities Assistance program [21] and USEPA (2007) (Table 2). The $\mathrm{pH}$ was not correlated with the analyzed parameters (Table 3).

The conductivity of the water samples from the farms studied does not go beyond the values recommended by the literature (Table 2) in most of the equine farms. In relation to the majority of ions (water table and semishallow groundwater), the calcium and magnesium concentrations were found within the acceptable limits for animal drink water $\left(\mathrm{Ca}^{2+}<500 \mathrm{mg} / \mathrm{L}, \mathrm{Mg}^{2+}<250 \mathrm{mg} / \mathrm{L}\right.$ and $\mathrm{Cl}^{-}$from 2 to 23) (Tables 1, 2).

Chlorides incorporated into the daily intake of water from farms with high and moderate concentrations of chloride (Table 1) are higher than the recommended levels (3000 mg/L, [22]). This should be considered because 
Table 2 Physicochemical parameters of water samples, depth of underground water sources and distance of farms to urban centers

\begin{tabular}{|c|c|c|c|c|c|c|c|c|c|}
\hline Farm No & $\mathrm{pH}$ & $\operatorname{CON}(\mu \mathrm{S} / \mathrm{cm})$ & $\begin{array}{l}\text { Total } \\
\text { hardness } \\
(\mathrm{mg} / \mathrm{L})\end{array}$ & $\begin{array}{l}\text { Chlorides } \\
\text { (mg/L) }\end{array}$ & $\begin{array}{l}\text { Nitrates } \\
\left(\mathrm{NO}_{3}-\mathrm{N}\right) \\
(\mathrm{mg} / \mathrm{L})\end{array}$ & TDS (mg/L) & Samples site & $\begin{array}{l}\text { Distance to city } \\
\text { of Buenos Aires } \\
(\mathrm{km})\end{array}$ & Depth (m) \\
\hline 1 & 7.30 & 317 & 124 & 42 & 1 & 156 & $\begin{array}{l}\text { General Las } \\
\text { Heras }\end{array}$ & 100 & $35-40$ \\
\hline 2 & 7.22 & 1208 & 307 & 48 & 2 & 846 & San Isidro & 38.6 & 60 \\
\hline 3 & 6.93 & 755 & 285 & 32 & 3.6 & & $\begin{array}{l}\text { Malvinas Argen- } \\
\text { tinas }\end{array}$ & 42.2 & 60 \\
\hline 4 & 7.11 & 809 & 200 & 18 & 2.5 & & Moreno & 42.1 & 60 \\
\hline 5 & 6.81 & 852 & 213 & 28 & 2.5 & & Pilar & 65.4 & 80 \\
\hline 6 & 6.75 & 741 & 239 & 20 & 0.5 & & Pilar & 61.1 & 70 \\
\hline 7 & 7.18 & 898 & 140 & 36 & 2.6 & & Cañuelas & 68.2 & 60 \\
\hline 8 & 7.16 & 919 & 151 & 33 & 6 & & Pilar & 61.1 & 50 \\
\hline 9 & 7.60 & 605 & 525 & 11 & 15 & 303 & $\begin{array}{l}\text { San Andrés de } \\
\text { Giles }\end{array}$ & 108 & 24 \\
\hline 10 & 6.96 & 817 & 178 & 19 & 0.1 & & Pilar & 61.1 & 50 \\
\hline 11 & 6.79 & 441 & 142 & 59 & 1.3 & & $\begin{array}{l}\text { General Las } \\
\text { Heras }\end{array}$ & 100 & 60 \\
\hline 12 & 6.89 & 836 & 135 & 30 & 0.1 & & Open Door & 83 & 30 \\
\hline 13 & 6.79 & 849 & 174 & 33 & 2 & & Pilar & 61.1 & 70 \\
\hline 14 & 6.60 & 680 & 680 & 16 & 30 & 342 & Las Heras & 100 & 60 \\
\hline 15 & 7.13 & 784 & 197 & 21 & 4.1 & & Las Heras & 100 & 60 \\
\hline 16 & 7.05 & 934 & 163 & 33 & 6.8 & & Moreno & 42.1 & 70 \\
\hline 17 & 7.04 & 841 & 150 & 37 & 0.1 & & Moreno & 42.1 & $60-70$ \\
\hline 18 & 7.70 & 625 & 550 & 10 & 12 & 313 & $\begin{array}{l}\text { San Andrés de } \\
\text { Giles }\end{array}$ & 108 & 20 \\
\hline 19 & 6.86 & 2482 & 754 & 196 & 3 & 1737 & Hurlingham & 33 & 40 \\
\hline 20 & 6.96 & 1541 & 530 & 128 & 2 & 1079 & Hurlingham & 33 & 60 \\
\hline 21 & 7.63 & 941 & 98 & 12 & 3 & 470 & Pilar & 61.1 & 40 \\
\hline 22 & 6.50 & 676 & 629 & 17 & 38 & 338 & $\begin{array}{l}\text { General Las } \\
\text { Heras }\end{array}$ & 100 & $14-16$ \\
\hline 23 & 7.73 & 453 & 102 & 21 & 2 & 227 & Pilar & 61.1 & $35-40$ \\
\hline 24 & 7.26 & 887 & 109 & 36 & 0.1 & & Chivilcoy & 167 & 70 \\
\hline 25 & 6.89 & 818 & 159 & 18 & 0.2 & & $\begin{array}{l}\text { Exaltación de la } \\
\text { Cruz }\end{array}$ & 84.5 & 40 \\
\hline 26 & 7.06 & 932 & 160 & 32 & 9 & & Hurlingham & 33 & 70 \\
\hline CEMA & 7.20 & 2600 & 1630 & & $<1$ & 1660 & & & \\
\hline USEPA & $6.5-8.5$ & 1000 & & & $<1$ & & & & \\
\hline Lewis [22] & & & 200 & 3000 & 400 & 6500 & & & \\
\hline
\end{tabular}

Water quality levels' guidelines: Canadian Environmental Quality Guidelines (CEMA); United States Environmental Protection Agency (USEPA)

CON conductivity, TDS total dissolved solids

high levels of chloride intake can cause various diseases in horses as electrolyte imbalances and colic. For this reason, the water quality, particularly chloride concentration, should be monitored every $48-72 \mathrm{~h}$, before symptoms of osmotic diarrhea appear since it can lead to equine colic. To avoid the disease, the equine farms can use better quality alternative water sources (surface or network), or groundwater from different wells and mix it to improve water quality to ensure animal health.
Hardness does not correlate with the parameters analyzed, while conductivity has a significant positive correlation with chlorides $(r=0.905, p=0.0001)$, with TDS $(r=0.996, p=0.0001)$ and depth $(r=0.634, p=0.0049)$, and a negative correlation with the distance to the city of Buenos Aires ( $r=-0.839, p=0.002)$ (Table 3$)$. This suggests that the more remote localities from the city have water with lower conductivity. High values of conductivity from the farms near the city of Buenos Aires may be due 
Table 3 Values of $r$ of Spearman's correlation

$\mathrm{pH} \quad \mathrm{CON}(\mu \mathrm{S} / \mathrm{cm}) \quad$ Total Hardness $(\mathrm{mg} / \mathrm{L}) \quad$ Chlorides $(\mathrm{mg} / \mathrm{L}) \quad$ Nitrates $(\mathrm{mg} / \mathrm{L}) \quad$ TDS $(\mathrm{mg} / \mathrm{L}) \quad$ Distance to city of
Buenos Aires (km)

\begin{tabular}{|c|c|c|c|c|c|c|c|}
\hline $\mathrm{pH}$ & 1 & & & & & & \\
\hline $\operatorname{CON}(\mu \mathrm{S} / \mathrm{cm})$ & $\begin{array}{l}-0.397 \text { nsc } \\
p=0.256\end{array}$ & 1 & & & & & \\
\hline Total Hardness & $\begin{array}{l}-0.584 \text { nsc } \\
p=0.076\end{array}$ & $\begin{array}{l}0.433 \mathrm{nsc} \\
p=0.211\end{array}$ & 1 & & & & \\
\hline Chlorides (mg/L) & $\begin{array}{l}-0317 \text { nsc } \\
p=0.372\end{array}$ & $\begin{array}{l}0.905^{*} \\
p=0.0001\end{array}$ & $\begin{array}{l}0.260 \mathrm{nsc} \\
p=0.467\end{array}$ & 1 & & & \\
\hline Nitrates (mg/L) & $\begin{array}{l}-0.466 \mathrm{nsc} \\
p=0.174\end{array}$ & $\begin{array}{l}-0.289 \text { nsc } \\
p=0.417\end{array}$ & $\begin{array}{l}0.482 \mathrm{nsc} \\
p=0.158\end{array}$ & $\begin{array}{l}-0.313 \text { nsc } \\
p=0.378\end{array}$ & 1 & & \\
\hline TDS (mg/L) & $\begin{array}{l}-0.407 \mathrm{nsc} \\
p=0.242\end{array}$ & $\begin{array}{l}0.996^{*} \\
p=0.0001\end{array}$ & $\begin{array}{l}0.425 \mathrm{nsc} \\
p=0.221\end{array}$ & $\begin{array}{l}0.913^{*} \\
p=0.0001\end{array}$ & $\begin{array}{l}-0.319 \mathrm{nsc} \\
p=0.368\end{array}$ & 1 & \\
\hline $\begin{array}{l}\text { Distance to city } \\
\text { of Buenos Aires } \\
(\mathrm{km})\end{array}$ & $\begin{array}{l}0.199 \mathrm{nsc} \\
p=0.580\end{array}$ & $\begin{array}{l}-0.839^{*} \\
p=0.002\end{array}$ & $\begin{array}{l}0.263 \mathrm{nsc} \\
p=0.942\end{array}$ & $\begin{array}{l}-0.812^{*} \\
p=0.004\end{array}$ & $\begin{array}{l}0.529 \mathrm{nsc} \\
p=0.115\end{array}$ & $\begin{array}{l}-0.852^{*} \\
p=0.002\end{array}$ & 1 \\
\hline Depth (m) & $\begin{array}{l}-0.026 \mathrm{nsc} \\
p=0.942\end{array}$ & $\begin{array}{l}0.634^{*} \\
p=0.049\end{array}$ & $\begin{array}{l}-0.271 \mathrm{nsc} \\
p=0.448\end{array}$ & $\begin{array}{l}0.739 * \\
p=0.015\end{array}$ & $\begin{array}{l}-0.646^{*} \\
p=0.043\end{array}$ & $\begin{array}{l}0.666^{*} \\
p=0.035\end{array}$ & $\begin{array}{l}-0.853^{*} \\
p=0.002\end{array}$ \\
\hline
\end{tabular}

CON conductivity, TDS total dissolved solids, nsc no significative correlation

Bold: $r$ and $p$ values of significative correlation ${ }^{*} p<0.05$

to domestic and industrial effluents (partially treated or untreated).

These results are also coincident with the PCA, where the first and second components explained $69 \%$ of the total variability. The first component (PC1) explained $43 \%$ of total variance and was mainly determined by total dissolved solids (eigenvector: 0.53 ), conductivity (0.51) and chlorides (0.49). Farms with the best water quality are the ones at the longest distance $(>80 \mathrm{~km})$ from the city of Buenos Aires (Fig. 2), meanwhile those close to the city have the greatest total dissolved solids, conductivity and chlorides (Table 2). PC2 accounts for $26 \%$ of the total variance and has strong positive weight for hardness (0.59) and nitrates (0.59), and negative score with depth (-0.46). The second axis showed a clear farms separation according to wells depth (negative end of the axis) and water nitrates and hardness (positive end of the axis).

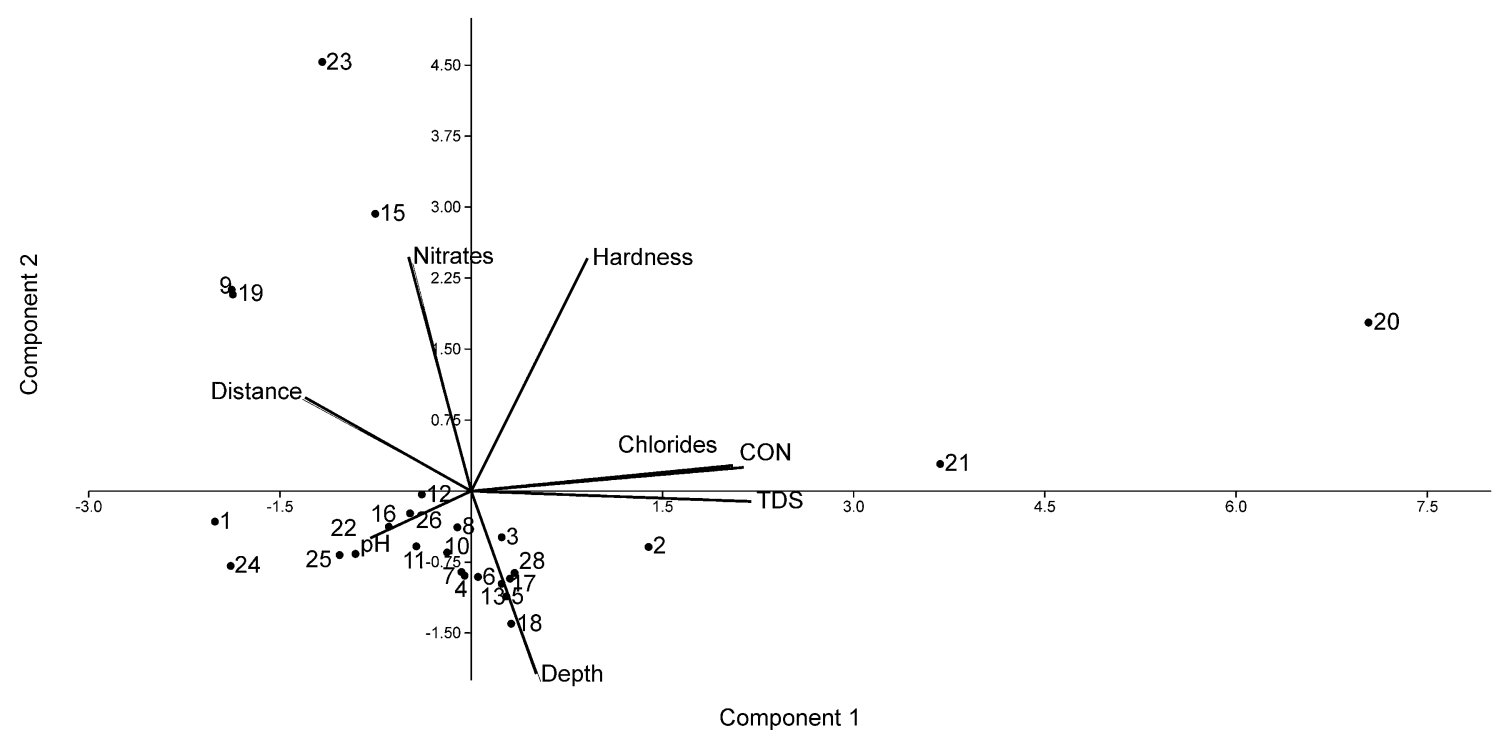

Fig. 2 Principal component analysis plot based on water quality parameters measured in 26 equine farms of the Buenos Aires Province, Argentina 
The values of total dissolved solids of all the samples were below the values suggested by Lewis [22]. However, in farm 19 (Hurlingham) this value is higher, although this is not considered to be within the range of dangerous values at which animals reject water consumption, even though productive losses have not shown yet (4000-3000 mg/L) $[5,22]$. The TDS presents a significant positive correlation with chlorides $(r=0.913, p=0.0001)$ and water well depth $(r=0.666, p=0.035)$, and a significant negative correlation with the distance to the city of Buenos Aires $(r=-0.852$, $p=0.002$ ). Chloride also is a concern in groundwater, and concentrations are increasing in many aquifers in the world, especially in urban areas. Elevated concentrations of chloride in streams can be toxic to some aquatic life and increase the potential corrosively of the water [23, 24].

Nitrates' concentration in $79 \%$ of the farms exceeded the limit considered optimal by CCME [16] and USEPA [17]. However, these values were below the levels suggested by Lewis [22] as triggers of conditions in equines (Table 2).

Nitrates have a significant negative correlation $(r=-0.65, p<0.005)$ in the depth of the water source (Table 3). The samples' number $9,14,18$ and 22 shows a higher concentration of nitrates (Table 2). This is possible since the water coming from the water table is liable to be affected with high concentrations of this ion for being in direct contact with the non-saturated zone; this can be seen in the most superficial samples.

Human activities can affect concentrations of dissolved solids in groundwater. Groundwater pumping can pull deep saline water upward to shallow depths, or in from the coast into freshwater aquifers. Human activities can add dissolved solids to recharging groundwater. Detergents, water softeners, fertilizers, road salt, urban runoff, and animal and human waste all contain elevated concentrations of dissolved solids that are delivered to groundwater by wastewater disposal, septic systems or direct application to the land surface $[25,26]$. The TDS results correspond with the results showed for the conductivity and to characteristics of the aquifers.

The results of the work show that there is a relative association between the water quality of drink used in the farms and the distance from these locations to the most important urban area (city of Buenos Aires). This suggests that sources of groundwater near to the city of Buenos Aires present a lower water quality for equine production $[13,27-29]$.

\section{Conclusion}

The rise in the demand of water resource and the scarcity and decline in its quality has exposed the necessity to evaluate the availability of the resource and its quality in order to guarantee the development of equine production [30] In conclusion, the water equine production farms in Buenos Aires Province was negatively related to the distance from Buenos Aires city. Equine farms closest to the city $(<80 \mathrm{~km})$ may present different problems to be considered: the excessive salinity and the presence of nitrates from anthropic origin.

Acknowledgements The authors are indebted to UBA Veterinary School and INPA (UBA-CONICET) for financial support.

Funding The funding was provided by Universidad de Buenos Aires (UBACYT 20020170100541BA).

\section{Compliance with ethical standards}

Conflict of interest The authors declare no conflicts of interest.

\section{References}

1. Cirelli AF, Volpedo AV (2011) Una visión multidisciplinaria de la gestión del agua en el Mercosur. "Enfoques multidisciplinarios de la Gestión Integrada del Agua" (EMGIA), Buenos Aires Argentina

2. Cirelli AF, Volpedo AV, Pérez Carrera AL (2013) La calidad de agua como factor clave en la producción animal. In: El agua en la producción agropecuaria, Buenos Aires, pp 11-38

3. Colahan P, Mathew JG (1998) Medicina y Cirugía Equina. Editorial Intermédica

4. Cunningham JG, Klein BG (2007) Veterinary physiology. Saunders Elsevier, Philadelphia

5. Klein BG (2014) Cunningham. Fisiología veterinaria, 5a edn. Elsevier España, Barcelona

6. Burgess BA, Lohmann KL, Blakley BR (2010) Excessive sulfate and poor water quality as a cause of sudden deaths and an outbreak of diarrhea in horses. Can Vet J 51(3):277-283

7. Hooda PS, Edwards AC, Anderson HA, Miller AA (2000) Review of water quality concerns in livestock farming areas. Sci Total Environ 250:143-167

8. Parvage MM, Ulén B, Kirchmann H (2015) Are horse paddocks threatening water quality through excess loading of nutrients. J Environ Manag 147:306-313

9. Vaccaro M, Liñeiro AG, Cirelli AF (2017) Management of equine production and its environmental impact: the case of settlements in Buenos Aires (Argentina). Sustain Agric Food Environ Res 5(1):17-24

10. Valeriani E, Herrero M, Sardi G, Garbo L, Orlando A, Maldonado V, Vacarezza D (2005) Water in equine production in Buenos Aires province-Argentina. Arch Latinoam Prod Anim 5(3):271-273

11. SENASA (2019). www.senasa.gov.ar. Accessed 1 Dec 2019

12. Armengol Vall S, Manzano Arellano M, Bea S, Pelizardi F, Ormaechea L, Martínez S (2016) Aportes al modelo hidrogeoquímico conceptual de la cuenca del río Matanza-Riachuelo. In: IX Congreso Argentino de Hidrogeología y VII Seminario Hispano-Latinoamericano Sobre Temas Actuales de la Hidrología Subterránea

13. Auge M, Hirata R, Lopez Vera F (2004) Vulnerabilidad a la contaminación por nitratos del acuífero Puelches en La Plata Argentina. Centro de Estudios de America Latina (CEAL) U.A.M S.C.H 
14. Ferral AE, Alaniz E, Tagle, MS, Petrusevski B (2014). Hydrogeochemical characterization of the presence of arsenic in the Puelche aquifer in the area of Mataderos. In: Litter MI, Nicolli HB, Meichtry JM, Quici N, Bundschuh J, Battachay P, Naidu R (eds) One century of the discovery of arsenicosis in latin America, Buenos Aires. CRC Press, Boca Raton, pp 157-158

15. APHA, AWWA, WPCF (2002) Métodos normalizados para el análisis de aguas potables y residuales. $22^{a}$ Ed. Díaz de Santos S.A

16. CCME (2005) Canadian environmental quality guidelines CEQFs. http://ceqgrcqe.ccme.ca/en/index.html. Accessed 12 Mar 2019

17. USEPA (2007) Water quality guidelines. United States Environmental Protection Agency. https://www.epa.gov/laws-regul ations/regulations. Accessed 12 Mar 2019

18. Hubert M, Rousseeuw P, Verdonck T (2009) Robust PCA for skewed data and its outlier map. Comput Stat Data Anal 53:2264-2274

19. Di Rienzo JA, Casanoves F, Balzarini MG (2011) InfoStat versión 2011. Grup

20. Canadian Environmental Quality Guidelines CEQFs (2005). http://ceqgrcqe.ccme.ca/en/index.html. Accessed 12 Mar 2019

21. Equine Facilities Assistance Program (2007). https://www.mspca .org/programsresources/pet-care-assistance/equine-assistance -program/. Accessed 10 Mar 2019

22. Lewis LD (1995) Equine clinical nutrition: feeding and care. Williams \& Wilkins, Philadelphia

23. Alberta Agriculture and Food (2005) Water requirements for livestock. Agdex 400/716-1

24. Tennis $M$ (2007). Water analysis interpretation for livestock. AgriFActs Agdex 400/716-2, pp 1-9
25. Manitoba Agriculture, Food and Rural Initiatives (2006) Evaluating water quality for livestock. http://www.gov.mb.ca/agricultur e/livestock/nutrition/bza01s06.html. Accessed 15 Mar 2019

26. National Research Council (2005) Mineral tolerance of animals, 2nd revised edn. National Academies Press, Washington, D.C.

27. Carretero S, Kruse E (2015) Iron and manganese content in groundwater on the northeastern coast of the Buenos Aires Province, Argentina. Environ Earth Sci 73(5):1983-1995

28. Carol ES, Kruse EE, Laurencena PC, Rojo A, Deluchi MH (2012) lonic exchange in groundwater hydrochemical evolution. Study case: the drainage basin of El Pescado creek (Buenos Aires province, Argentina). Environ Earth Sci 65(2):421-428

29. Galindo G, Sainato C, Dapeña C, Fernández-Turiel JL, Gimeno D, Pomposiello MC, Panarello HO (2007) Surface and groundwater quality in the northeastern region of Buenos Aires Province, Argentina. J S Am Earth Sci 23(4):336-345

30. Westerndorf ML (2012) Environmental impacts of equine operations: a US Department of Agriculture multistate project. J Equine Vet Sci 32:324-326

31. InfoStat, FCA, Univ. Nac. Córdoba, Argentina, vol 8, pp 195-199. http://www.infostat.com.ar. Accessed 15 Dec 2018

Publisher's Note Springer Nature remains neutral with regard to jurisdictional claims in published maps and institutional affiliations. 